Research Paper

\title{
Gender-related Outcome in Bladder Cancer Patients undergoing Radical Cystectomy
}

\author{
Renate Pichler $^{1}$, Josef Fritz ${ }^{2}$, Isabel Heidegger1, Wilhelm Oberaigner ${ }^{3,4}$, Wolfgang Horninger1, Margarethe \\ Hochleitner $^{5}$ \\ 1. Department of Urology; \\ 2. Department of Medical Statistics, Informatics and Health Economics; \\ 3. Department of Clinical Epidemiology of the Tyrolean State Hospitals Ltd, Cancer Registry of Tyrol; \\ 4. Department of Public Health, Health Services Research and HTA, UMIT - University for Health Sciences, Medical Informatics and Technology, Hall in \\ Tyrol, Austria; \\ 5. Women's Health Centre and Coordination Centre for Equality, Affirmative Action for Women and Gender Research, Medical University of Innsbruck, \\ A-6020 Innsbruck, Austria. \\ $\triangle$ Corresponding author: Renate Pichler, MD, FEBU, PhD. Medical University of Innsbruck. Department of Urology. Anichstrasse 35, A-6020 Innsbruck, \\ Austria; Email: Renate.Pichler@i-med.ac.at; Tel.: +43 (0) 512504 24811; Fax: +43 (0) 51250428365 \\ (c) Ivyspring International Publisher. This is an open access article distributed under the terms of the Creative Commons Attribution (CC BY-NC) license \\ (https:// creativecommons.org/licenses/by-nc/4.0/). See http://ivyspring.com/terms for full terms and conditions.
}

Received: 2017.05.22; Accepted: 2017.08.29; Published: 2017.09.30

\begin{abstract}
Background: The impact of gender on oncological outcome after radical cystectomy (RC) is not fully understood yet. The aim of the study was to evaluate gender-related differences in histopathological parameters and prognosis of patients with bladder cancer undergoing RC.

Methods: A retrospective analysis of a 10-year single-center cystectomy database was performed. Kaplan-Meier survival and Cox-regression analyses with sex-specific interactions were performed to determine the impact of gender on recurrence-free survival (RFS), cancer-specific survival (CSS), and overall survival (OS), in addition to established clinicopathological factors.

Results: 259 patients (212 [81.8\%] men and 47 [18.2\%] women) were enrolled. Although women had a greater propensity for extravesical $(\geq \mathrm{pT} 3)$ disease $(53.2 \%$ vs. $33.9 \%, p=0.03)$ and heterotopic urinary diversion $(72.3 \%$ vs. $49.5 \%, p=0.006)$, gender did not independently predict RFS, CSS or OS on multivariate analysis. Extravesical tumor disease was the sole independent predictor concerning RFS (hazard ratio $[H R]=4.70 ; p<0.001)$, CCS $(H R=2.77 ; p=0.013)$, and OS $(H R=1.93 ; p=0.041)$. Orthotopic urinary diversion (HR=0.36; $p=0.002)$ had an independent effect only on RFS. Rates of 5 -year RFS (73.7\% vs. $48.3 \%$; $p=0.001)$, CSS $(72.5 \%$ vs. $44.9 \% ; p<0.001)$ and OS $(62.6 \%$ vs. $37.8 \%$; $p<0.001)$ were higher in orthotopic versus heterotopic diversions.

Conclusion: In our series, women presented with more advanced tumors and higher rates of heterotopic urinary diversions, but their survival outcome was not significantly inferior to that of men. Extravesical disease was independently related to poorer survival after RC.
\end{abstract}

Key words: bladder cancer; cystectomy, outcome; gender; survival; prognostic factor

\section{Introduction}

According to the European Association of Urology (EAU) guidelines, radical cystectomy (RC) is the standard treatment for localized muscle-invasive and recurrent, high-risk, non-muscle invasive bladder cancer (BC), [1]. However, the 5-year survival rate for these patients is a mere 50\% [2-6]. Significant efforts are being made to determine predictive parameters for stratifying patients into different prognostic groups, and thus identifying those who will benefit most from neoadjuvant or adjuvant treatment [7].

Extravesical disease and a positive lymph node (LN) status are currently the most validated predictors of recurrence and distant metastasis [8-9]. Moreover, a delay of more than three months from 
diagnosis to RC may influence the oncological outcome negatively [10-11]. Delayed diagnosis would be one possible explanation for women with advanced tumor stage at the initial diagnosis [12], resulting in higher rates of extravesical tumor disease at RC, and a delayed acceptance of orthotopic bladder substitution [13-16]. Nevertheless, the functional and long-term oncological outcome, and the postoperative quality of life after ileal neobladder in women were reported to be similar to those in men [16-18]. Irrespective of gender, continent cutaneous diversion or the orthotopic neobladder was associated with lower rates of cancer-specific death [19]. However, when adjusted for pathological stage, no cancer-specific survival differences were noted between the ileal conduit and the orthotopic neobladder [20].

Gender-related differences in survival outcome after RC remain a debated issue, with contradictory reported data. The female gender was an independent predictor of poor cancer-specific survival in various multicenter studies [14,21-23], including one of the largest with 30.310 patients [24]. In contrast, other trials report no gender-specific differences in survival following RC [25] despite a higher pathological tumor stage in women than in men, even when matched for different histopathological characteristics [25-28].

In this retrospective study, we reviewed our prospectively maintained 10-year cystectomy database. We evaluated histopathological parameters and gender-specific differences in recurrence-free (RFS), cancer-specific (CSS) and overall survival (OS) among patients who underwent RC and postoperative follow-up at our institution.

\section{Material and Methods}

\section{Patients}

A single-center cystectomy database [29] with data collected prospectively from January 2000 was reviewed retrospectively with the approval of the local ethics committee (study number UN3532; 274/4.4 and AN2015-0085; 348/4.10). The medical records of those patients with localized muscle-invasive or recurrent, high-risk, non-muscle-invasive BC [30], who had undergone RC and urinary diversion until March 2016 were reviewed retrospectively. All procedures performed in studies involving human participants were in accordance with the ethical standards of the institutional ethics committee of the Medical University Innsbruck and with the 1964 Helsinki declaration and its later amendments or comparable ethical standards.

\section{Inclusion and exclusion criteria}

Patients who had undergone cystectomy for benign disease or due to a non-urothelial cancer, those who had received neoadjuvant chemotherapy prior to RC, those who were followed elsewhere postoperatively, and patients with evidence of distant metastasis on standard imaging before surgery were excluded. Finally, 259 patients who had undergone routine follow-up (with a minimum of 6 months) at our outpatient uro-oncology department were included in the study.

\section{Surgery}

Standard RC consisted of removal of the bladder, distal ureters and proximal urethra in both genders, including the prostate and seminal vesicles in men, and the adjacent vagina plus uterus in women $[1,31]$. The technique and outcome of "urethra-sparing" surgery in orthotopic ileal neobladder replacement for women have been described previously by our study group [16]; the procedure includes the preservation of the sphincter mechanism and most of the lateral vaginal wall [16]. Extended bilateral pelvic lymphadenectomy was routinely performed in all patients as recommended and described by the EAU guidelines for muscle-invasive BC $[1,31]$. Intraoperative frozen sections were obtained from the urethra and distal ureters as standard. Tumor-negative frozen sections of the urethral resection margins were required in all patients with orthotopic bladder substitution [32].

\section{Follow-up investigations}

According to our institutional practice, follow-up visits were scheduled every 3 months in the first postoperative year, then at 6-month intervals until the end of the fifth year, and once every year thereafter. Each control visit involved a complete laboratory blood examination with blood gas analysis and PSA in men, analysis of folic acid and vitamin B12 levels starting in the fifth postoperative year, urinary dipstick analysis to exclude urinary tract infection, urinary cytology of voided urine, catheterized urine and urethral washings according to the Papanicolaou classification [33], measurement of residual urine in orthotopic ileal neobladders, and standard imaging (chest and abdominopelvic CT scan at every second control, alternated with chest radiography and abdominal ultrasound). Local pelvic recurrence was defined as tumor recurrence in the surgical bed, and distant metastasis as lymphogenic or hematogenic metastatic tumor spread [7].

\section{Statistical analysis}

Patient characteristics of men and women were 
compared with the Mann-Whitney $U$ test for numerical parameters, the Cochran-Armitage test for trend for ordinal, and Fisher's exact test for nominal parameters. One-year, 3-, 5-, and 10-year survival rates and survival curves were calculated using the Kaplan-Meier product-limit estimation approach. Survival curves were compared by the log-rank test. The impact of baseline and histopathological factors on RFS, CSS, and OS was evaluated in univariate as well as multivariate Cox proportional hazards models. To determine whether histopathological factors have different effects for men and women on RFS, CCS and OS, an interaction term between sex and each predictor was included.Statistics were performed with SPSS, version 22.0 (IBM Corp., Armonk, NY), assuming a significance level of $a=0.05$ (2-tailed). Figures and tables were produced with Microsoft Excel and GraphPad PrismTM6 (GraphPad Software Inc., La Jolla, CA).

\section{Results}

\section{Descriptive characteristics}

The mean age was 68.3 years (median 69; range 33-88 years), the male/female ratio 4.5:1 (212 men and 47 women). Orthotopic ileal neobladder and cutaneous catheterizable umbilical pouch were performed in $121(46.7 \%)$ patients and incontinent diversions (ileal conduit and ureterocutanostomy) in 138 (53.3\%). The mean number of resected pelvic LNs was 19.9 (median, 17; range, 2-56) per patient. Forty-three $(16.6 \%)$ patients had occult pelvic LN spread at surgery, including 29 with a singular pelvic LN metastasis (pN1), 10 with pN2 and 4 patients with $\mathrm{pN} 3$. Extravesical tumor disease $(\geq \mathrm{pT} 3$ vs. $\mathrm{pT} 2: 72.1 \%$ vs. $20.9 \% ; p<0.001)$ and advanced age $(\geq 70$ vs. $<70$ years: $62.8 \%$ vs. $37.2 \%$; $p=0.046$ ) were the sole significant predictors of a positive $\mathrm{LN}$ status in cystectomy specimens.

After RC, 40 patients $(15.4 \%)$ received adjuvant chemotherapy (4 cycles of gemcitabine $1000 \mathrm{mg} / \mathrm{m}^{2}$ on days 1,8 and 15 , and cisplatin $70 \mathrm{mg} / \mathrm{m}^{2}$ on day $2 ; 1$ cycle $=28$ days): 30 (75\%) with pT3/T4 disease (13 of them with simultaneous LN metastasis), and 10 (25\%) with pathological $\mathrm{T} 2$ disease and a concomitant $\mathrm{pN}+$ status.

\section{Oncologic outcome following radical cystectomy}

Seventy $(27.0 \%)$ of 259 patients developed recurrence and $82(31.7 \%)$ of 259 patients died during a mean (range) postoperative surveillance period of 19 (2-265) months. Among those patients with recurrence, local pelvic recurrence was present in 19
(27.1\%) of 70 patients, and distant metastasis in 51 (72.9\%) of 70 patients, respectively. Overall RFS, CCS and OS were $80.2 \%, 85.2 \%$ and $83.5 \%$ at 1 year; $66.7 \%$, $73 \%$ and $66.8 \%$ at 3 years; $61.1 \%, 58.2 \%$ and $49.5 \%$ at 5 years; $39.4 \%, 52.4 \%$ and $30.4 \%$ at 10 years, respectively.

Table 1 summarizes the descriptive and histopathological patient characteristics according to gender-related differences. Women had a greater propensity for pathological extravesical $\geq \mathrm{pT} 3$ disease $(53.2 \%$ [25/47] vs. 33.9\% [72/212], $p=0.03)$, and consequently higher rates of heterotopic urinary diversion $(72.3 \%$ [34/47] vs. $49.5 \%$ [105/212], $p=0.006)$ than in men.

Table 1. Gender-specific differences in descriptive and histopathological factors.

\begin{tabular}{|c|c|c|c|}
\hline Parameters & $\begin{array}{l}\text { Men } \\
(n=212)\end{array}$ & $\begin{array}{l}\text { Women } \\
(\mathrm{n}=47)\end{array}$ & $P$-value \\
\hline $\begin{array}{l}\text { Age at surgery, mean } \pm \mathrm{SD} \text {, } \\
\text { median (range), years }\end{array}$ & $\begin{array}{l}68.6 \pm 9.5,70.0 \\
(37-88)\end{array}$ & $\begin{array}{l}67.1 \pm 11.2 \\
69.0(17-82)\end{array}$ & $0.487^{*}$ \\
\hline Urinary diversion, $\mathrm{n}(\%)$ & & & $0.006^{* *}$ \\
\hline Heterotopic & $105(49.5 \%)$ & $34(72.3 \%)$ & \\
\hline Orthotopic & $107(50.5 \%)$ & $13(27.7 \%)$ & \\
\hline $\mathrm{T}$ stage at $\mathrm{RC}, \mathrm{n}(\%)$ & & & $0.030^{* * *}$ \\
\hline pT0 & $3(1.5 \%)$ & & \\
\hline pT1/pTIS & $78(36.8 \%)$ & $12(25.5 \%)$ & \\
\hline $\mathrm{pT} 2 \mathrm{a} / 2 \mathrm{~b}$ & $59(27.8 \%)$ & $10(21.3 \%)$ & \\
\hline$\geq \mathrm{pT} 3 \mathrm{a}$ & $72(33.9 \%)$ & $25(53.2 \%)$ & \\
\hline Concomitant CIS at RC, $\mathrm{n}(\%)$ & $127(59.9 \%)$ & $25(53.2 \%)$ & $0.417^{* *}$ \\
\hline $\mathrm{R}$ positivity at $\mathrm{RC}, \mathrm{n}(\%)$ & $11(5.2 \%)$ & $3(6.4 \%)$ & $0.624^{* *}$ \\
\hline $\begin{array}{l}\text { Lympho-vascular invasion (LVI) } \\
\text { at RC, } \mathrm{n}(\%)\end{array}$ & $49(23.1 \%)$ & $12(25.5 \%)$ & $0.647^{* *}$ \\
\hline $\begin{array}{l}\text { Total resected LN count, mean } \pm \\
\text { SD median (range) }\end{array}$ & $\begin{array}{l}19.8 \pm 10.017 .0 \\
(2-56)\end{array}$ & $\begin{array}{l}20.5 \pm 12.3 \\
16.0(7-51)\end{array}$ & $0.717^{*}$ \\
\hline $\begin{array}{l}\text { Positive } \mathrm{LN} \text { count, mean } \pm \mathrm{SD} \text {, } \\
\text { (range) }\end{array}$ & $0.7 \pm 3.1,(0-28)$ & $\begin{array}{l}0.6 \pm 2.4 \\
(0-15)\end{array}$ & $0.900^{*}$ \\
\hline $\mathrm{N}$ stage at $\mathrm{RC}, \mathrm{n}(\%)$ & & & $1.000^{* *}$ \\
\hline $\mathrm{pN} 0$ & $177(83.5 \%)$ & $39(83.0 \%)$ & \\
\hline $\mathrm{pN}+$ & $35(16.5 \%)$ & $8(17.0 \%)$ & \\
\hline Recurrence, $\mathrm{n}(\%)$ & $55(25.9 \%)$ & $15(31.9 \%)$ & $0.468^{* *}$ \\
\hline $\begin{array}{l}\text { Follow-up after RC, median } \\
\text { (range), months }\end{array}$ & $20.0(6-265)$ & $16.0(6-117)$ & $0.423^{*}$ \\
\hline
\end{tabular}

Nevertheless, the female gender did not independently predict a poorer oncological outcome after RC, neither on univariate nor on multivariate analysis (Tables 2 and 3). Including an interaction term between sex and each histopathological predictor in the Cox regression model, the impact of age, $\mathrm{T}$ stage at $\mathrm{RC}$, concomitant CIS, the number of resected LNs at RC, LN status at RC and the type of urinary diversion on RFS, CCS and OS did not differ between men and women. 


\section{Univariate and multivariate analysis concerning postoperative survival}

On univariate analysis, pathological tumor stage at $\mathrm{RC}$ (hazard ratio $[\mathrm{HR}]=6.63,95 \% \mathrm{CI}: 3.21-13.69$, $p<0.001)$ and continent urinary diversion $(\mathrm{HR}=0.44$, 95\% CI: 0.26-0.71, $p=0.001$ ) were associated with RFS. Advanced tumor stage ( $\mathrm{HR}=4.87,95 \% \mathrm{CI}$ : 2.42-9.78, $p<0.001)$, positive $\mathrm{LN}$ status $(\mathrm{HR}=2.08,95 \% \mathrm{CI}$ : 1.18-3.67, $p=0.011)$, advanced age $(\mathrm{HR}=1.04,95 \% \mathrm{CI}$ : 1.01-1.06, $p=0.013$ ), and continent urinary diversion (HR=0.35, 95\% CI: 0.20-0.59, $p<0.001$ ) were predictors of CSS. Moreover, advanced age (HR=1.04, 95\% CI:
1.02-1.07, $p=0.001)$, extravesical tumor disease $(\mathrm{HR}=3.04,95 \% \mathrm{CI}: 1.78-5.20, p<0.001)$ and continent urinary diversion $\quad(\mathrm{HR}=0.42, \quad 95 \% \mathrm{CI}: \quad 0.27-0.67$, $p<0.001$ ) influenced OS significantly (Table 2).

On multivariate analysis, extravesical tumor disease was the sole parameter, independently related to RFS (HR=4.70, 95\% CI: 2.09-10.62, $p<0.001)$, CCS $(\mathrm{HR}=2.77,95 \%$ CI: 1.24-6.18, $p=0.013)$ and OS (HR=1.93, 95\% CI: 1.03-3.63, $p=0.041)$. Besides, orthotopic urinary diversion independently predicted a prolonged RFS (HR=0.36, 95\% CI: 0.19-0.67, $p=0.002)$, Table 3 .

Table 2. Univariate Cox regression model evaluating the association between histopathological, baseline characteristics and recurrence-free survival (RFS), cancer-specific survival (CSS) and overall survival (OS) after RC.

\begin{tabular}{|c|c|c|c|c|c|c|c|c|c|}
\hline \multirow[t]{2}{*}{ Predictors } & \multicolumn{3}{|c|}{ Recurrence-free survival } & \multicolumn{3}{|c|}{ Cancer-specific survival } & \multicolumn{3}{|c|}{ Overall survival } \\
\hline & HR & $95 \% \mathrm{CI}$ & P value & HR & $95 \% \mathrm{CI}$ & P value & HR & $95 \% \mathrm{CI}$ & P value \\
\hline \multicolumn{10}{|l|}{ Gender } \\
\hline Men & 1.00 & & & 1.00 & & & 1.00 & & \\
\hline Women & 0.70 & $0.39-1.24$ & 0.225 & 0.93 & $0.49-1.73$ & 0.810 & 1.03 & $0.59-1.81$ & 0.914 \\
\hline Age* & 1.01 & $0.98-1.03$ & 0.461 & 1.04 & $1.01-1.06$ & 0.013 & 1.04 & $1.01-1.07$ & 0.001 \\
\hline \multicolumn{10}{|l|}{ T stage } \\
\hline pT1/CIS & 1.00 & & & 1.00 & & & 1.00 & & \\
\hline pT2a/2b & 3.00 & $1.35-6.69$ & 0.007 & 2.44 & $1.11-5.40$ & 0.027 & 1.66 & $0.88-3.12$ & 0.115 \\
\hline$\geq \mathrm{pT} 3 \mathrm{a}$ & 6.63 & $3.21-13.69$ & $<0.001$ & 4.87 & $2.42-9.78$ & $<0.001$ & 3.04 & $1.77-5.20$ & $<0.001$ \\
\hline Concomitant CIS & 0.65 & $0.41-1.04$ & 0.073 & 0.68 & $0.42-1.10$ & 0.117 & 0.72 & $0.47-1.10$ & 0.130 \\
\hline \multicolumn{10}{|l|}{ LN status at RC } \\
\hline $\mathrm{pN}-$ & 1.00 & & & 1.00 & & & 1.00 & & \\
\hline $\mathrm{pN}+$ & 1.77 & $0.99-3.16$ & 0.052 & 2.08 & $1.18-3.67$ & 0.011 & 1.60 & $0.94-2.72$ & 0.086 \\
\hline Resected LN count* & 1.00 & $0.97-1.03$ & 0.981 & 0.99 & $0.96-1.02$ & 0.675 & 0.99 & $0.96-1.02$ & 0.427 \\
\hline \multicolumn{10}{|l|}{ Urinary diversion } \\
\hline Heterotopic & 1.00 & & & 1.00 & & & 1.00 & & \\
\hline Orthotopic & 0.44 & $0.26-0.71$ & 0.001 & 0.35 & $0.20-0.59$ & $<0.001$ & 0.42 & $0.27-0.67$ & $<0.001$ \\
\hline
\end{tabular}

*Cox regression with continuous covariate

Table 3. Multivariate Cox regression model evaluating the association between histopathological, baseline characteristics and recurrence-free survival (RFS), cancer-specific survival (CSS) and overall survival (OS) after RC.

\begin{tabular}{|c|c|c|c|c|c|c|c|c|c|}
\hline \multirow[t]{2}{*}{ Predictors } & \multicolumn{3}{|c|}{ Recurrence-free survival } & \multicolumn{3}{|c|}{ Cancer-specific survival } & \multicolumn{3}{|c|}{ Overall survival } \\
\hline & HR & $95 \% \mathrm{CI}$ & P value & HR & $95 \% \mathrm{CI}$ & P value & HR & $95 \% \mathrm{CI}$ & P value \\
\hline \multicolumn{10}{|l|}{ Gender } \\
\hline Men & 1.00 & & & 1.00 & & & 1.00 & & \\
\hline Women & 1.20 & $0.58-2.47$ & 0.628 & 1.05 & $0.47-2.32$ & 0.905 & 1.22 & $0.60-2.47$ & 0.582 \\
\hline Age* & 0.98 & $0.95-1.01$ & 0.169 & 1.01 & $0.98-1.05$ & 0.527 & 1.02 & $0.99-1.05$ & 0.265 \\
\hline \multicolumn{10}{|l|}{ T stage } \\
\hline pT1/CIS & 1.00 & & & 1.00 & & & 1.00 & & \\
\hline $\mathrm{pT} 2 \mathrm{a} / 2 \mathrm{~b}$ & 3.11 & $1.31-7.41$ & 0.010 & 1.98 & $0.82-4.78$ & 0.128 & 1.44 & $0.71-2.94$ & 0.311 \\
\hline$\geq \mathrm{pT} 3 \mathrm{a}$ & 4.70 & $2.08-10.62$ & $<0.001$ & 2.77 & $1.24-6.18$ & 0.013 & 1.93 & $1.03-3.63$ & 0.041 \\
\hline Concomitant CIS & 0.68 & $0.39-1.18$ & 0.173 & 0.80 & $0.44-1.47$ & 0.477 & 0.74 & $0.44-1.26$ & 0.269 \\
\hline \multicolumn{10}{|l|}{ LN status at RC } \\
\hline $\mathrm{pN}-$ & 1.00 & & & 1.00 & & & 1.00 & & \\
\hline $\mathrm{pN}+$ & 1.19 & $0.61-2.37$ & 0.602 & 1.59 & $0.81-3.13$ & 0.180 & 1.20 & $0.64-2.26$ & 0.568 \\
\hline Resected LN count* & 0.99 & 0.96-1.02 & 0.645 & 0.99 & $0.96-1.03$ & 0.795 & 0.99 & $0.96-1.02$ & 0.650 \\
\hline \multicolumn{10}{|l|}{ Urinary diversion } \\
\hline Heterotopic & 1.00 & & & 1.00 & & & 1.00 & & \\
\hline Orthotopic & 0.36 & $0.19-0.67$ & 0.002 & 0.54 & $0.27-1.05$ & 0.068 & 0.62 & $0.36-1.09$ & 0.100 \\
\hline
\end{tabular}

${ }^{*}$ Cox regression with continuous covariate 
A

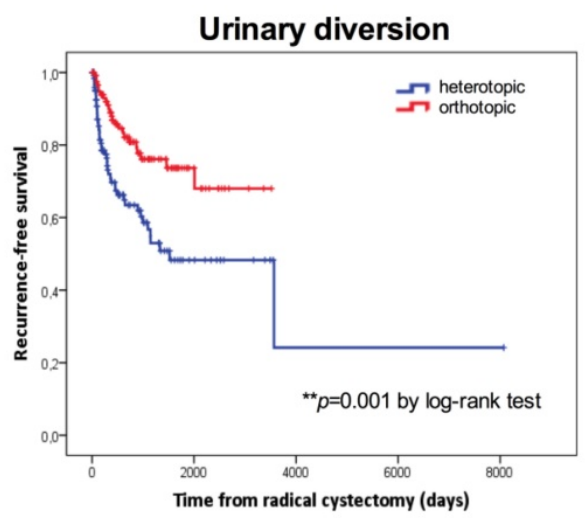

C

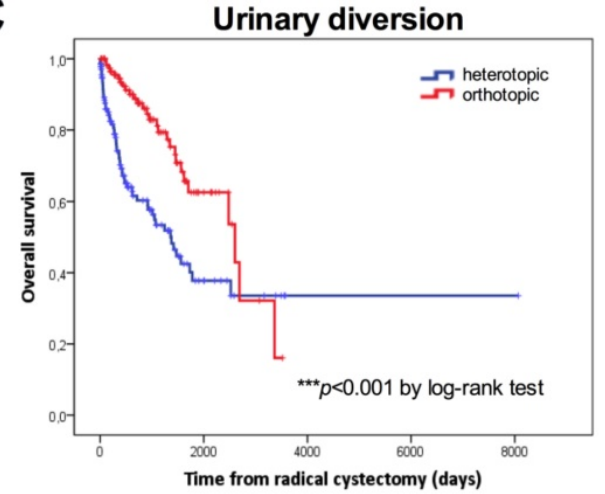

B

T stage at RC

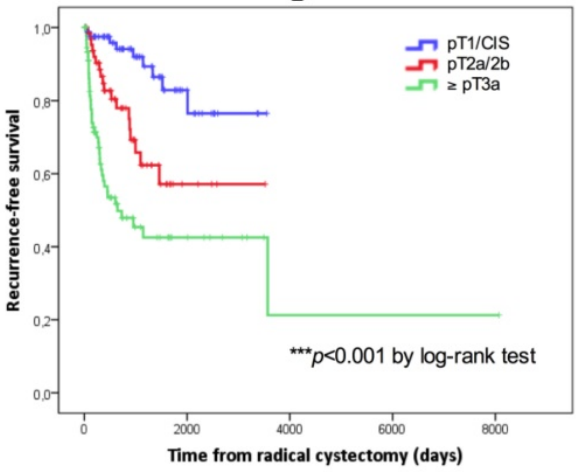

D

T stage at RC

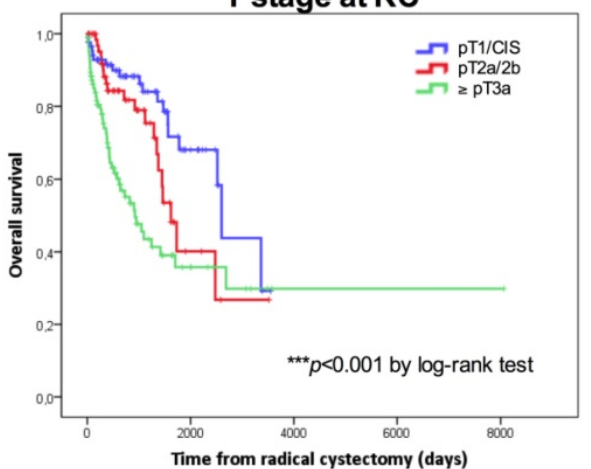

Figure 1. Kaplan-Meier survival curves. Overall survival (OS) and recurrence-free survival (RFS) in days according to the type of urinary diversion (A, C) and $T$ stage $(B, D)$ and at radical cystectomy. $P$ values by log-rank test; $*_{p}<0.05 ; * *_{p}<0.01 ; * * * p<0.001$.
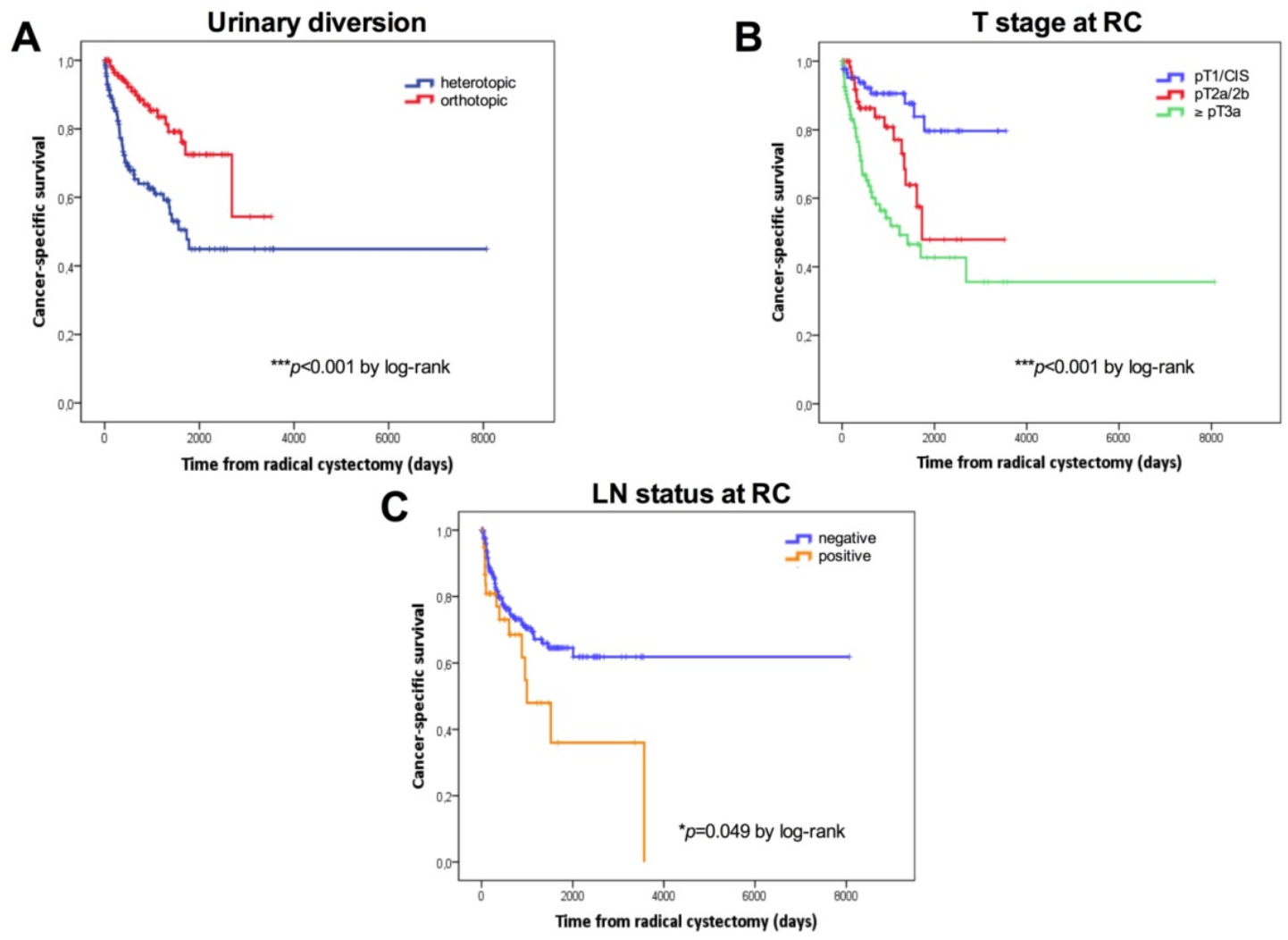

Figure 2. Kaplan-Meier survival curves. Cancer-specific survival (CSS) in days stratified by the type of urinary diversion (A), T stage (B) and lymph node status (C) at radical cystectomy. $P$ values by log-rank test; ${ }^{*} p<0.05 ; * *<<0.01 ; * * *<0.001$. 


\section{Kaplan-Meier survival curves}

Tumor stage, the type of urinary diversion, and positive LN disease were confirmed as the most important predictors of RFS, CSS and OS univariately. For patients with $\leq \mathrm{pT} 1 \mathrm{BC}(\mathrm{n}=90,34.7 \%)$, 5-year RFS, CCS and OS were $82.9 \%, 79.6 \%$ and $68.1 \%$, respectively. For patients with pT2 BC (n=69, 26.6\%), 5 -year RFS, CCS and OS were $57.1 \%, 47.9 \%$ and $40.2 \%$, respectively. For patients with extravesical disease $(\mathrm{n}=97,37.5 \%)$, 5-year RFS, CCS and OS were $42.5 \%$, $42.7 \%$ and $35.8 \%$, respectively. Patients with continent urinary diversions had a significantly better RFS (5-year: $73.7 \%$ vs. $48.3 \%$ ), CCS (5-year: $72.5 \%$ vs. $44.9 \%)$ and OS (62.6\% vs. $37.8 \%)$ than those who underwent incontinent diversions. Patients with positive LNs $(n=39,15.1 \%)$ had a significantly poorer CSS than LN-negative patients (5-year CSS: $64.6 \%$ vs. $36 \%)$.

Kaplan-Meier curves according to the type of urinary diversion (heterotopic vs. orthotopic, median: 50 months vs. NE, $p=0.001$ for RFS; median: 45.2 vs 85.5 months, $p<0.001$ for OS) and $\mathrm{T}$ stage at $\mathrm{RC}$ (NMIBC vs. $\geq$ pT3, $p<0.001$ for RFS; median: 85.5 vs. 30.3 months, $p<0.001$ for OS) for RFS and OS are shown in Figures 1A-1D. Survival analysis revealed a significant negative association between heterotopic urinary diversion $(p<0.001)$, advanced $\mathrm{T}$ stage at RC $(p<0.001)$, positive LN disease at RC $(p=0.049)$ and CSS (Figures 2A-2C).

\section{Discussion}

$B C$ is marked by numerous gender-specific differences. First, the incidence of bladder cancer is three to four times higher in men than in women [34]. Gender-related disparities in the prevalence of urothelial carcinoma of the bladder may partly be explained by potential molecular mechanisms, such as differences in the metabolism of carcinogens via hepatic enzymes [35], or the activity of the sex steroid hormone pathway aggravating the $\mathrm{BC}$ growth adversely by both, stimulatory and inhibitory effects [36-38]. Androgen receptor (AR) signaling seems to induce bladder carcinogenesis and progression $[37,39]$. Whereas the estrogen receptor (ER) $\alpha$ prevented cancer growth in vitro and in vivo [40], ER $\beta$ promoted tumor progression [41]. In contrast to the $E R a / E R \beta$ pathway, AR signals enhanced the preventive effect of androgen-deprivation therapy (ADT) on bladder cancer recurrence, as AR positivity (HR=0.27; $p=0.005)$ in cancer tissue was an independent predictor of reduced cancer recurrence in patients receiving ADT for two primary urogenital cancers (prostate and bladder), [42].

Despite the lower incidence in women than in men, the former was more likely to have an advanced tumor stage at initial presentation as well as at time of RC $[12,14,24]$, consequently with lower rates of orthotopic bladder substitution [13-15] and poorer survival rates after RC [43]. Although population-based, multicenter cancer registry analyses have confirmed a significantly higher rate of cancer recurrence and cancer-specific mortality in women after RC [14,21-24,44-45], gender was no independent prognostic factor on propensity score matching, as reported recently [46]. In patients with metastatic disease undergoing cisplatin-based chemotherapy, survival outcomes were similar in men and women, even when matched for histopathological factors such as performance status and metastasis [47]. In our series, the female gender did not independently predict a poorer RFS, CSS or OS compared to males, although women had a greater propensity for $\geq \mathrm{pT} 3$ disease $(53.2 \%$ vs. $33.9 \%)$. These data are in line with previous reports, showing that a higher tumor stage in women at the time of surgery did not simultaneously translate into a poor survival outcome [26,28]. On Cox regression with sex interaction term, the effect of clinicopathological predictors on RFS, CCS and OS did not differ between genders. However, women had a $20 \%$ higher risk of tumor recurrence and all-cause mortality on multivariate analysis, but without statistical significance. This fact may be explained by the limited number of cases included in our observational study (without sample size estimate). Hence these results must be interpreted with caution. Whereas women had similar survival rates when matched for clinicopathological factors, higher tumor and nodal stage was a justified explanation for the poor oncological outcome in women than in an unmatched male control group [27]. In contrast, Kluth et al. (2014) mentioned that a higher risk of cancer-specific mortality in females after RC cannot be explained solely by gender-specific disparities in tumor stage, lymph node status or lymphovascular invasion [14]. In line with these findings, Dabi et al. confirmed that the female gender independently predicts recurrence and cancer-specific survival, despite comparable histopathological factors between the genders [48]. Nevertheless, advanced tumor stage and a positive LN status at RC are known to be the most important predictors of recurrence after RC [9-10,26,49]. In another study by Stein et al (2001), the 5-year RFS in LN-positive patients after RC was a mere $35 \%$ [2]. In our study, the 5-year CCS was also significantly lower for $\mathrm{LN}$ positive than $\mathrm{LN}$ negative patients $(36.0 \%$ vs. $64.6 \%)$. In our study group, which was well balanced regarding $\mathrm{T}$ stage $(\leq \mathrm{pT} 1: \mathrm{n}=90$ [35.3\%], pT2: $\mathrm{n}=68$ $[26.7 \%], \geq \mathrm{pT} 3: \mathrm{n}=97[38.0 \%]), \geq \mathrm{pT} 3$ stage was the sole 
independent predictor of a poor RFS $(\mathrm{HR}=4.70)$, CCS $(\mathrm{HR}=2.77)$ as well as $\mathrm{OS}(\mathrm{HR}=1.93)$, while positive $\mathrm{LN}$ disease $(\mathrm{HR}=2.08, p=0.011)$ was a predictor of a poor CCS on univariate analysis, but not multivariately.

In addition, we found that orthotopic urinary diversion $(\mathrm{HR}=0.36, p=0.002)$ was independently related to a favorable RFS. Several authors stated that the risk of urethral recurrence after orthotopic bladder substitution was significantly lower than after heterotopic diversion [50-51]. Moreover, orthotopic or continent bladder replacement was associated with a lower risk of cancer-specific mortality [20]. We found a positive tendency towards advanced $\mathrm{T}$ stage in heterotopic urinary diversions ( $\geq \mathrm{pT} 3$ vs. pT2: $44.1 \%$ vs. $24.3 \% ; p=0.057)$, which might explain the poor outcome of heterotopic diversion. Regarding gender-related differences, women had a higher tumor stage at RC, as well as higher rates of heterotopic bladder substitution $(72.3 \%$ vs. $49.5 \%)$. A time delay from the initial symptoms to the first urological visit, delayed time to surgery, and longer waiting times, especially in women, have been mentioned as possible reasons for their advanced disease [12,21,52-54]. However, the prognostic impact of such time delay must be evaluated in further trials before drawing any final conclusions [46]. Nonetheless, patients who were referred late to the urologist had a higher risk of mortality and poor survival after RC [55].

One of the major limitations of the present observational study is its retrospective character and single-center design. Other limitations include a small number of patients, no case number calculations compared to multicenter cancer registries, restricted methods of interpreting statistically independent predictors of postoperative survival, and a certain selection bias in terms of excluding those patients who had received neoadjuvant chemotherapy and those who were followed elsewhere postoperatively.

\section{Conclusions}

In conclusion, extravesical tumor disease at the time of surgery was the most important prognostic factor, and thus the sole independent parameter in predicting RFS, CCS, and OS after RC, but without gender-specific differences. This subgroup of patients should be studied in future clinical trials because there is an urgent necessity for effective adjuvant therapy. In women, higher rates of advanced tumor disease and consecutive heterotopic bladder substitution were not necessarily associated with a poorer oncologic outcome compared to men.

\section{Abbrevations}

Androgen-deprivation therapy=ADT; androgen receptor $=\mathrm{AR}$; bladder cancer $=\mathrm{BC}$; cancer-specific survival=CSS; carcinoma in situ $=C I S$; estrogen receptor=ER; European Association of Urology=EAU; lymph node=LN; overall survival=OS; radical cystectomy=RC; recurrence-free survival=RFS;

\section{Acknowledgements}

We thank Roberta Rohregger, Siegrid Amort and Hannes Steiner for their continuous support.

\section{Funding}

This study was funded by the Medical Research Foundation Tyrol (MFF Tirol, project number 273).

\section{Competing Interests}

The authors have declared that no competing interest exists.

\section{References}

1. Alfred Witjes J, Lebret T, Compérat EM, Cowan NC, De Santis M, Bruins HM, Hernández V, Espinós EL, Dunn J, Rouanne M, Neuzillet $Y$, Veskimäe E, van der Heijden AG, Gakis G, Ribal MJ. Updated 2016 EAU Guidelines on Muscle-invasive and Metastatic Bladder Cancer. Eur Urol. 2016; pii: S0302-2838(16)30290-1. doi: 10.1016/j.eururo.2016.06.020.

2. Stein JP, Lieskovsky G, Cote R, Groshen S, Feng AC, Boyd S, Skinner E, Bochner B, Thangathurai D, Mikhail M, Raghavan D, Skinner DG. Radical cystectomy in the treatment of invasive bladder cancer: long-term results in 1,054 patients. J Clin Oncol. 2001 Feb 1;19(3):666-75.

3. Stein JP, Skinner DG. Radical cystectomy for invasive bladder cancer: long-term results of a standard procedure. World J Urol. 2006 Aug;24(3):296-304

4. Dalbagni G, Genega E, Hashibe M, Zhang ZF, Russo P, Herr H, Reuter V. Cystectomy for bladder cancer: a contemporary series. J Urol. 2001 Apr;165(4):1111-6.

5. Bassi P, Ferrante GD, Piazza N, Spinadin R, Carando R, Pappagallo G, Pagano F. Prognostic factors of outcome after radical cystectomy for bladder cancer: a retrospective study of a homogeneous patient cohort. J Urol. 1999 May;161(5):1494-7

6. Ghoneim MA, el-Mekresh MM, el-Baz MA, el-Attar IA, Ashamallah A. Radical cystectomy for carcinoma of the bladder: critical evaluation of the results in 1,026 cases. J Urol. 1997 Aug;158(2):393-9.

7. Cheng L, Weaver AL, Leibovich BC, Ramnani DM, Neumann RM, Scherer BG, Nehra A, Zincke H, Bostwick DG. Predicting the survival of bladder carcinoma patients treated with radical cystectomy. Cancer. 2000 May $15 ; 88(10): 2326-32$.

8. Ghoneim MA, Abdel-Latif M, el-Mekresh M, Abol-Enein H, Mosbah A, Ashamallah A, el-Baz MA. Radical cystectomy for carcinoma of the bladder: 2,720 consecutive cases 5 years later. J Urol. 2008 Jul;180(1):121-7. doi: 10.1016/j.juro.2008.03.024.

9. Huguet J. Follow-up after radical cystectomy based on patterns of tumour recurrence and its risk factors. Actas Urol Esp. 2013 Jun;37(6):376-82.

10. Gore JL, Lai J, Setodji CM, Litwin MS, Saigal CS; Urologic Diseases in America Project. Mortality increases when radical cystectomy is delayed more than 12 weeks: results from a Surveillance, Epidemiology, and End Results-Medicare analysis. Cancer. 2009 Mar 1;115(5):988-96. doi: 10.1002/cncr.24052.

11. Nielsen ME, Palapattu GS, Karakiewicz PI, Lotan Y, Bastian PJ, Lerner SP, Sagalowsky AI, Schoenberg MP, Shariat SF. A delay in radical cystectomy of $>3$ months is not associated with a worse clinical outcome. BJU Int. 2007 Nov;100(5):1015-20.

12. Richards KA, Ham S, Cohn JA, Steinberg GD. Urinary tract infection-like symptom is associated with worse bladder cancer outcomes in the Medicare population: Implications for sex disparities. Int J Urol. 2016 Jan;23(1):42-7. doi: 10.1111/iju.12959.

13. Mungan NA, Kiemeney LA, van Dijck JA, van der Poel HG, Witjes JA. Gender differences in stage distribution of bladder cancer. Urology. 2000 Mar;55(3):368-71

14. Kluth LA, Rieken M, Xylinas E, Kent M, Rink M, Rouprêt M, Sharifi N Jamzadeh A, Kassouf W, Kaushik D, Boorjian SA, Roghmann F, Noldus J, Masson-Lecomte A, Vordos D, Ikeda M, Matsumoto K, Hagiwara M, Kikuchi E, Fradet Y, Izawa I, Rendon R, Fairey A, Lotan Y, Bachmann A, Zerbib M, Fisch M, Scherr DS, Vickers A, Shariat SF. Gender-specific differences in clinicopathologic outcomes following radical cystectomy: an international multi-institutional study of more than 8000 patients. Eur Urol. 2014 Nov;66(5):913-9. 
15. Wu SD, Simma-Chang V, Stein JP. Pathologic guidelines for orthotopic urinary diversion in women with bladder cancer: a review of the literature. Rev Urol. 2006;8(2):54-60.

16. Pichler R, Zangerl F, Leonhartsberger N, Stöhr B, Horninger W, Steiner H. Orthotopic bladder replacement in women: focus on functional results of a retrospective, single-centre study. Scand J Urol. 2013 Aug;47(4):295-301. doi: 10.3109/00365599.2012.738429.

17. Rouanne M, Legrand G, Neuzillet Y, Ghoneim T, Cour F, Letang N, Yonneau L, Hervé JM, Botto H, Lebret T. Long-term women-reported quality of life after radical cystectomy and orthotopic ileal neobladder reconstruction. Ann Surg Oncol. 2014 Apr;21(4):1398-404.

18. Granberg CF, Boorjian SA, Crispen PL, Tollefson MK, Farmer SA, Frank I, Blute ML. Functional and oncological outcomes after orthotopic neobladder reconstruction in women. BJU Int. 2008 Dec;102(11):1551-5.

19. Mitra AP, Quinn DI, Dorff TB, Skinner EC, Schuckman AK, Miranda G, Gill IS, Daneshmand S. Factors influencing post-recurrence survival in bladder cancer following radical cystectomy. BJU Int. 2012 Mar;109(6):846-54.

20. Yossepowitch O, Dalbagni G, Golijanin D, Donat SM, Bochner BH, Herr HW, Fair WR, Russo P. Orthotopic urinary diversion after cystectomy for bladder cancer: implications for cancer control and patterns of disease recurrence. J Urol. 2003 Jan;169(1):177-81.

21. Otto W, May M, Fritsche HM, Dragun D, Aziz A, Gierth M, Trojan L, Herrmann E, Moritz R, Ellinger J, Tilki D, Buchner A, Höfner T, Brookman-May S, Nuhn P, Gilfrich C, Roigas J, Zacharias M, Denzinger S, Hohenfellner M, Haferkamp A, Müller SC, Kocot A, Riedmiller H, Wieland WF, Stief CG, Bastian PJ, Burger M. Analysis of sex differences in cancer-specific survival and perioperative mortality following radical cystectomy: results of a large German multicenter study of nearly 2500 patients with urothelial carcinoma of the bladder. Gend Med. 2012 Dec;9(6):481-9.

22. May M, Bastian PJ, Brookman-May S, Fritsche HM, Tilki D, Otto W, Bolenz C, Gilfrich C, Trojan L, Herrmann E, Moritz R, Tiemann A, Müller SC, Ellinger J, Buchner A, Stief CG, Wieland WF, Höfner T, Hohenfellner M, Haferkamp A, Roigas J, Zacharias M, Nuhn P, Burger M. Gender-specific differences in cancer-specific survival after radical cystectomy for patients with urothelial carcinoma of the urinary bladder in pathologic tumor stage T4a. Urol Oncol. 2013 Oct;31(7):1141-7.

23. Aziz A, Shariat SF, Roghmann F, Brookman-May S, Stief CG, Rink M, Chun FK, Fisch M, Novotny V, Froehner M, Wirth MP, Schnabel MJ, Fritsche HM, Burger M, Pycha A, Brisuda A, Babjuk M, Vallo S, Haferkamp A, Roigas J, Noldus J, Stredele R, Volkmer B, Bastian PJ, Xylinas E, May M. Prediction of cancer-specific survival after radical cystectomy in pT4a urothelial carcinoma of the bladder: development of a tool for clinical decision-making. BJU Int. 2016 Feb;117(2):272-9.

24. Thorstenson A, Hagberg O, Ljungberg B, Liedberg F, Jancke G, Holmäng S, Malmström PU, Hosseini A, Jahnson S. Gender-related differences in urothelial carcinoma of the bladder: a population-based study from the Swedish National Registry of Urinary Bladder Cancer. Scand J Urol. 2016 Aug;50(4):292-7.

25. Kaushik D, Frank I, Eisenberg MS, Cheville JC, Tarrell R, Thapa P, Thompson $\mathrm{RH}$, Booriian SA. Gender-specific survival following radical cystectomy for pT4 bladder cancer. World J Urol. 2014 Dec;32(6):1433-9.

26. Soave A, Dahlem R, Hansen J, Weisbach L, Minner S, Engel O, Kluth LA, Chun FK, Shariat SF, Fisch M, Rink M. Gender-specific outcomes of bladder cancer patients: a stage-specific analysis in a contemporary, homogenous radical cystectomy cohort. Eur J Surg Oncol. 2015 Mar;41(3):368-77.

27. Mitra AP, Skinner EC, Schuckman AK, Quinn DI, Dorff TB, Daneshmand S. Effect of gender on outcomes following radical cystectomy for urothelial carcinoma of the bladder: a critical analysis of 1,994 patients. Urol Oncol. 2014 Jan;32(1):52.e1-9.

28. Patafio FM, Robert Siemens D, Wei X, Booth CM. Is there a gender effect in bladder cancer? A population-based study of practice and outcomes. Can Urol Assoc J. 2015; 9:269-74

29. Heidegger I, Oberaigner W, Horninger W, Pichler R. High incidence of clinically significant concomitant prostate cancer in patients undergoing radical cystectomy for bladder cancer: A 10-year single-center experience. Urol Oncol. 2016; pii: S1078-1439(16)30370-2. doi: 10.1016/j.urolonc.2016.11.004.

30. Sylvester RJ, van der Meijden AP, Oosterlinck W, Witjes JA, Bouffioux C, Denis L, Newling DW, Kurth K. Predicting recurrence and progression in individual patients with stage Ta, T1 bladder cancer using EORTC risk tables: a combined analysis of 2596 patients from seven EORTC trials. Eur Urol 2006;49(3):466-5.

31. Witjes JA, Compérat E, Cowan NC, De Santis M, Gakis G, Lebret T, Ribal MJ, Van der Heijden AG, Sherif A; European Association of Urology. EAU guidelines on muscle-invasive and metastatic bladder cancer: summary of the 2013 guidelines. Eur Urol 2014:65:778-92

32. Akkad T, Gozzi C, Deibl M, Müller T, Pelzer AE, Pinggera GM, Bartsch G, Steiner $\mathrm{H}$. Tumor recurrence in the remnant urothelium of females undergoing radical cystectomy for transitional cell carcinoma of the bladder: long-term results from a single center. J Urol. 2006;175(4):1268-71; discussion 1271 .

33. Owens CL, Vandenbussche CJ, Burroughs FH, Rosenthal DL. A review of reporting systems and terminology for urine cytology. Cancer Cytopathol. 2013 Jan;121(1):9-14
34. Torre LA, Bray F, Siegel RL, Ferlay J, Lortet-Tieulent J, Jemal A. Global cancer statistics, 2012. CA Cancer J Clin. 2015 Mar;65(2):87-108

35. Dobruch J, Daneshmand S, Fisch M, Lotan Y, Noon AP, Resnick MJ, Shariat SF, Zlotta AR, Boorjian SA. Gender and Bladder Cancer: A Collaborative Review of Etiology, Biology, and Outcomes. Eur Urol. 2016 Feb;69(2):300-10.

36. Miyamoto H, Yao JL, Chaux A, Zheng Y, Hsu I, Izumi K, Chang C, Messing EM, Netto GJ, Yeh S. Expression of androgen and oestrogen receptors and its prognostic significance in urothelial neoplasm of the urinary bladder. BJU Int. 2012; 109(11):1716-26

37. Miyamoto H, Zheng Y, Izumi K. Nuclear hormone receptor signals as new therapeutic targets for urothelial carcinoma. Curr Cancer Drug Targets. 2012; 12(1):14-22.

38. Lucca I, Klatte T, Fajkovic H, de Martino M, Shariat SF. Gender differences in incidence and outcomes of urothelial and kidney cancer. Nat Rev Urol. 2015 Oct;12(10):585-92. doi: 10.1038/nrurol.2015.232.

39. Miyamoto $H$, Yang $Z$, Chen $Y T$, Ishiguro $H$, Uemura $H$, Kubota $Y$, Nagashima Y, Chang YJ, Hu YC, Tsai MY, Yeh S, Messing EM, Chang C. Promotion of bladder cancer development and progression by androgen receptor signals. J Natl Cancer Inst. 2007 Apr 4;99(7):558-68.

40. Hsu I, Yeh CR, Slavin S, Miyamoto H, Netto GJ, Tsai YC, Muyan M, Wu XR, Messing EM, Guancial EA, Yeh S. Estrogen receptor alpha prevents bladder cancer via INPP4B inhibited akt pathway in vitro and in vivo. Oncotarget. 2014 Sep 15;5(17):7917-35.

41. Hsu I, Chuang KL, Slavin S, Da J, Lim WX, Pang ST, O'Brien JH, Yeh S. Suppression of ER $\beta$ signaling via ER $\beta$ knockout or antagonist protects against bladder cancer development. Carcinogenesis. 2014 Mar;35(3):651-61.

42. Izumi K, Ito $Y$, Miyamoto H, Miyoshi Y, Ota J, Moriyama M, Murai T, Hayashi $\mathrm{H}$, Inayama $\mathrm{Y}$, Ohashi K, Yao M, Uemura H. Expression of androgen receptor in non-muscle-invasive bladder cancer predicts the preventive effect of androgen deprivation therapy on tumor recurrence. Oncotarget. 2016 Mar 22;7(12):14153-60.

43. Liu S, Yang T, Na R, Hu M, Zhang L, Fu Y, Jiang H, Ding Q. The impact of female gender on bladder cancer-specific death risk after radical cystectomy: a meta-analysis of 27,912 patients. Int Urol Nephrol. 2015 Jun;47(6):951-8.

44. Rink M, Lee DJ, Kent M, Xylinas E, Fritsche HM, Babjuk M, Brisuda A, Hansen J, Green DA, Aziz A, Cha EK, Novara G, Chun FK, Lotan Y, Bastian PJ, Tilki D, Gontero P, Pycha A, Baniel J, Mano R, Ficarra V, Trinh QD, Tagawa ST, Karakiewicz PI, Scherr DS, Sjoberg DD, Shariat SF; Bladder Cancer Research Consortium. Predictors of cancer-specific mortality after disease recurrence following radical cystectomy. BJU Int. 2013 Mar;111(3 Pt B):E30-6.

45. Messer JC, Shariat SF, Dinney $C P$, Novara $G$, Fradet $Y$, Kassouf $W$, Karakiewicz PI, Fritsche HM, Izawa JI, Lotan Y, Skinner EC, Tilki D, Ficarra V, Volkmer BG, Isbarn H, Wei C, Lerner SP, Curiel TJ, Kamat AM, Svatek RS. Female gender is associated with a worse survival after radical cystectomy for urothelial carcinoma of the bladder: a competing risk analysis. Urology. 2014 Apr;83(4):863-7

46. Wolff I, Brookman-May S, May M. Sex difference in presentation and outcomes of bladder cancer: biological reality or statistical fluke? Curr Opin Urol. 2015 Sep;25(5):418-26.

47. Haines L, Bamias A, Krege S, Lin CC, Hahn N, Ecke TH, Moshier E, Sonpavde G, Godbold J, Oh WK, Galsky MD. The impact of gender on outcomes in patients with metastatic urothelial carcinoma. Clin Genitourin Cancer. 2013 Sep;11(3):346-52

48. Dabi Y, Rouscoff Y, Delongchamps NB, Sibony M, Saighi D, Zerbib M, Peyraumore M, Xylinas E. [Negative prognostic impact of female gender on oncological outcomes following radical cystectomy]. Prog Urol. 2016 Feb;26(2):83-8

49. Moschini M, Karnes RJ, Sharma V, Gandaglia G, Fossati N, Dell'Oglio P, Cucchiara V, Capogrosso P, Shariat SF, Damiano R, Salonia A, Montorsi F, Briganti A, Gallina A, Colombo R. Patterns and prognostic significance of clinical recurrences after radical cystectomy for bladder cancer: A 20-year single center experience. Eur J Surg Oncol. 2016 May;42(5):735-43.

50. Nieder AM, Sved PD, Gomez P, Kim SS, Manoharan M, Soloway MS. Urethral recurrence after cystoprostatectomy: implications for urinary diversion and monitoring. Urology. 2004 Nov;64(5):950-4.

51. Hassan JM, Cookson MS, Smith JA Jr, Chang SS. Urethral recurrence in patients following orthotopic urinary diversion. J Urol. 2004 Oct;172(4 Pt 1):1338-41.

52. Santos F, Dragomir A, Kassouf W, Franco EL, Aprikian A. Predictors of preoperative delays before radical cystectomy for bladder cancer in Quebec, Canada: a population-based study. BJU Int. 2015 Mar;115(3):389-96.

53. Johnson EK, Daignault S, Zhang Y, Lee CT. Patterns of hematuria referral to urologists: does a gender disparity exist? Urology. 2008; 72(3):498-502; discussion 502-3

54. Henning A, Wehrberger M, Madersbacher S, Pycha A, Martini T, Comploj E, Jeschke K, Tripolt C, Rauchenwald M. Do differences in clinical symptoms and referral patterns contribute to the gender gap in bladder cancer? BJU Int. 2013 Jul;112(1):68-73.

55. Santos F, Dragomir A, Kassouf W, Franco E, Aprikian A. Urologist referral delay and its impact on survival after radical cystectomy for bladder cancer. Curr Oncol. 2015 Feb;22(1):e20-6. 